\title{
Trace Eyeblink Conditioning Increases CA1 Excitability in a Transient and Learning-Specific Manner
}

\author{
James R. Moyer Jr., Lucien T. Thompson, and John F. Disterhoft \\ Department of Cell and Molecular Biology and Institute for Neurosciences, Northwestern University Medical School, \\ Chicago, Illinois 60611-3008
}

Time-dependent, learning-related changes in hippocampal excitability were evaluated by recording from rabbit CA1 pyramidal neurons in slices prepared at various times after acquisition of trace eyeblink conditioning. Increased excitability (reduced postburst afterhyperpolarizations and reduced spike-frequency adaptation) was seen as early as $1 \mathrm{hr}$ after acquisition to behavioral criterion, was maximal in neurons studied $24 \mathrm{hr}$ later, and returned to baseline within $7 \mathrm{~d}$, whereas behavioral performance remained asymptotic for months. Neurons were held at $-67 \mathrm{mV}$ to equate voltage-dependent effects. No learningrelated effects were observed on input resistance, actionpotential amplitude or duration, or resting membrane potential. The excitability changes were learning-specific, because they were not seen in neurons from very slow learning (exhibited
$<30 \%$ conditioned responses after 15 training sessions) or from pseudoconditioned control rabbits. Neurons from rabbits that displayed asymptotic behavioral performance after longterm retention testing (an additional training session $14 \mathrm{~d}$ after learning) were also indistinguishable from control neurons. Thus, the increased excitability of CA1 neurons was not performance- or memory-dependent. Rather, the time course of increased excitability may represent a critical window during which learning-specific alterations in postsynaptic excitability of hippocampal neurons are important for consolidation of the learned association elsewhere in the brain.

Key words: afterhyperpolarization; spike-frequency adaptation; associative learning; memory; consolidation; in vitro; hippocampus
Behavioral pharmacology and lesion data suggest that a consolidation process involving transfer of learned information from a temporary labile form to a stable long-lasting form is required for the creation of persistent memories (Müller and Pilzecker, 1900; Hebb, 1949; Thompson, 1967; McGaugh and Herz, 1972). Since the initial observation that bilateral resection of the medial temporal lobe of patient H.M. resulted in severe memory impairments (Scoville and Milner, 1957), much research has focused on the function of the hippocampus and related medial temporal lobe structures for both normal learning and memory consolidation (McGaugh, 1966; McGaugh and Alperin, 1966; Berger et al., 1983; Squire, 1986, 1987; Buzsáki, 1989; Cohen and Eichenbaum, 1993). Research in primates, including humans, demonstrates that lesions restricted to the hippocampus produce severe memory deficits in numerous tasks (Zola-Morgan et al., 1986; Victor and Agamanolis, 1990; Alvarez et al., 1995). Hippocampal lesions also selectively impair memory of recently acquired information, while leaving more remote memories intact, suggestive of a role for the hippocampus in memory consolidation (Zola-Morgan and Squire, 1990).

We have adopted classical conditioning of the rabbit eyeblink response as a model system for studying the neural substrates of associative learning and memory (Disterhoft et al., 1994b). We use a higher-order variant of the eyeblink task called trace conditioning. In the trace eyeblink conditioning paradigm, the condi-

\footnotetext{
Received March 11, 1996; revised May 28, 1996; accepted May 30, 1996.

This work was supported by National Institutes of Health Grants RO1 MH47340, RO1 AG08796, and RO1 DA07633 to J.F.D. We thank F. Cutting, J. Power, D. Heintz, and J. Hauser for technical assistance, and Drs. C. Weiss and T. H. Brown for helpful discussions.

Correspondence should be addressed to Dr. James R. Moyer Jr., Department of Psychology, Yale University, P.O. Box 208205, New Haven, CT 06520-8205.

Copyright (C) 1996 Society for Neuroscience $0270-6474 / 96 / 165536-11 \$ 05.00 / 0$
}

tioned stimulus (CS) both precedes and terminates before presentation of the unconditioned stimulus (US) such that an intervening trace (stimulus-free) interval is interposed between the two stimuli. When rabbits are trained using the trace conditioning paradigm with a sufficiently long trace interval (e.g., 500 $\mathrm{msec}$ ), acquisition depends on an intact hippocampus (Solomon et al., 1986; Moyer et al., 1990; Kim et al., 1995). During trace conditioning, the few CRs elicited by hippocampectomized rabbits are inappropriately timed (Solomon et al., 1986; Moyer et al., 1990), lending support to the hypothesis that the hippocampus is involved in temporal processing (Solomon, 1980; Rawlins, 1985).

Rabbits not only fail to learn trace eyeblink conditioning when lesioned before acquisition (Moyer et al., 1990), but they also show no retention or reacquisition when lesioned immediately after learning (Kim et al., 1995). However, retention is intact when hippocampectomy is performed $30 \mathrm{~d}$ after acquisition, presumably after consolidation has occurred (Kim et al., 1995). Similar learning and memory deficits in trace eyeblink conditioning have also been reported using reversible inactivation of the hippocampus (Tocco et al., 1993). Extensive data demonstrate widespread changes in the hippocampus after eyeblink conditioning. For example, in vivo recording studies have correlated increased activity of hippocampal neurons with acquisition of eyeblink conditioning (Berger et al., 1983; Solomon et al., 1986; Weiss et al., 1996). A variety of biochemical and immunocytochemical changes also occur throughout the hippocampus after eyeblink conditioning (Bank et al., 1988; Olds et al., 1989; Van der Zee et al., 1994).

The in vitro hippocampal slice preparation permits evaluation of the electrophysiological properties of hippocampal pyramidal neurons independent of inputs from other brain regions to study changes localized to the hippocampus. Previous studies have 
shown that the calcium-dependent slow afterhyperpolarization (AHP) is significantly reduced in CA1 neurons from hippocampal slices prepared from conditioned but not pseudoconditioned control rabbits (Disterhoft et al., 1986; Coulter et al., 1989; SanchezAndres and Alkon, 1991). To date, no studies have examined changes in hippocampal CA1 neurons after acquisition of hippocampus-dependent trace eyeblink conditioning, nor has there been any evaluation of the temporal duration that learningrelated changes remain in the hippocampus after trace conditioning. To address these questions, intracellular current-clamp recordings were performed on CA1 pyramidal neurons in slices taken from rabbits at various time intervals after acquisition of trace eyeblink conditioning. Previous reports of these data have appeared in abstract form (Moyer et al., 1993, 1994b). A parallel series of studies was also conducted on CA3 pyramidal neurons (Thompson et al., 1996b).

\section{MATERIALS AND METHODS}

Behavioral training. Subjects were New Zealand albino rabbits (Oryctolagus cuniculus), purchased from Hazelton rabbitry (Denver, PA), and maintained in accordance with guidelines established by the USDA and approved and managed by Northwestern University's Animal Care Committee. Rabbits received $500 \mathrm{msec}$ trace eyeblink conditioning or pseudoconditioning as described previously (Moyer et al., 1990; Thompson et al., 1992, 1996a). Briefly, rabbits were fitted with restraining headbolts and trained in pairs in individual sound-attenuated chambers for daily 80 trial sessions (mean intertrial interval, $45 \mathrm{sec}$ ). The CS was a $100 \mathrm{msec}, 85 \mathrm{~dB}, 6 \mathrm{kHz}$ tone presented via stereo headphones. The US was a $150 \mathrm{msec}, 3.5 \mathrm{psi}$ corneal airpuff sufficient to elicit a reliable extension of the nictitating membrane (NM, or third eyelid) as the unconditioned response (UR). Rabbits were trained to a behavioral criterion of $80 \%$ CRs in a training session. An eyeblink response was counted as a CR if it occurred after CS onset but before US onset. Pseudoconditioned rabbits received explicitly unpaired presentations of the CS and US ( 80 CS- and 80 US-alone trials per day presented in pseudorandom order) and were session-matched to control for nonspecific effects unrelated to associative learning (e.g., sensitization). Behavioral experiments were controlled by an IBM PC clone computer using custom hardware and software described elsewhere (Akase et al., 1994; Thompson et al., 1994).

Experimental design. Trace conditioned rabbits were trained to a criterion of $80 \%$ CRs. Two primary control populations were used: experimentally naive and pseudoconditioned rabbits (session-matched to the trace-conditioned animals). Rabbits that failed to reach criterion within 15 sessions served as an additional control population (Slow-learning) and were studied separately (Disterhoft et al., 1988a). Slices were prepared from all pseudoconditioned and slow-learning rabbits $24 \mathrm{hr}$ after their last training session.

To evaluate the time course of learning-related changes in rabbit CA1 neuron electrophysiology, rabbits that acquired the trace conditioning task were assigned to one of six groups based on the time interval $(1 \mathrm{hr}$, $24 \mathrm{hr}, 3 \mathrm{~d}, 5 \mathrm{~d}, 7 \mathrm{~d}$, or $14 \mathrm{~d}$ ) between when behavioral criterion was attained and when slices were prepared (i.e., for rabbits in the $5 \mathrm{~d}$ group slices were prepared on the 5th day after reaching criterion). A seventh group of rabbits (Retention) was maintained in their home cages for 2 weeks after acquisition, without additional training. On the 14th day, these rabbits received an additional conditioning session (80 paired CS-US trials). The next day, slices were prepared from these rabbits. Thus, electrophysiological data were collected from a total of three control groups (Naive, Pseudoconditioned, Slow-learners), six experimental groups $(1 \mathrm{hr}, 24 \mathrm{hr}, 3 \mathrm{~d}, 5 \mathrm{~d}, 7 \mathrm{~d}$, or $14 \mathrm{~d})$, and one behavioral retention group (Retention), yielding a total of 10 groups.

Another group of rabbits (from which no electrophysiological data were gathered) also received trace eyeblink conditioning. These rabbits $(n=7)$ were trained to criterion and later used to study behavioral retention of the CR. These rabbits received 20 paired CS-US trials at various intervals ranging from $24 \mathrm{hr}$ to $180 \mathrm{~d}$ after reaching criterion. Each rabbit was tested for retention a maximum of four times.

Off-line analyses of the electrophysiological data were conducted blind; however, the data collection was not done blind. We designed the study in this manner because of the extensive number of experimental groups and inherent variations in acquisition rates between rabbits trained using the long-interval trace-conditioning paradigm. This required continuous monitoring and evaluation of behavioral acquisition so we could minimize the number of subjects required for training, yet still yield adequate samples of neurons in the various groups. We deemed this to be a scientifically acceptable procedure for several reasons. First, previous blind studies conducted in our laboratory (Disterhoft et al., 1986, 1988b; deJonge et al., 1990) and other laboratories (LoTurco et al., 1988; Coulter et al., 1989; Sanchez-Andres and Alkon, 1991; Woody et al., 1991) have observed conditioning-specific changes in postsynaptic properties of hippocampal or cortical neurons. That is, a substantial amount of data exists supporting the basic phenomenon of postsynaptic excitability changes in cortical neurons after eyeblink conditioning. Second, every stable, healthy CA1 pyramidal cell (see below) from which electrophysiological data were collected during an experiment was included in the study. Third, there were no significant differences between the number of cells studied per animal among all of the control and experimental groups. Fourth, as mentioned above, all data analyses were conducted using blind procedures. Finally, completely blind procedures have not always been used when studying learning-related changes with invertebrate preparations after basic phenomena had been established in blind studies (Carew et al., 1981; Hawkins et al., 1983; Walters and Byrne, 1983; Alkon, 1984; Frysztak and Crow, 1994). The present data must be evaluated with these considerations in mind.

Slice preparation. Hippocampal slices were prepared from 76 young rabbits $(1.8 \pm 0.3$ months) using a modification of our previously published procedure (Moyer et al., 1992). We used two solutions: a normal artificial CSF (aCSF; composition in mM: $124 \mathrm{NaCl}, 3 \mathrm{KCl}, 1.3 \mathrm{MgSO}_{4}$, $1.24 \mathrm{NaH}_{2} \mathrm{PO}_{4}, 2.4 \mathrm{CaCl}_{2}, 26 \mathrm{NaHCO}_{3}, 10$ D-glucose; gassed with $95 \%$ $\mathrm{O}_{2} / 5 \% \mathrm{CO}_{2}, \mathrm{pH} 7.4$ ) and a sucrose-aCSF, which contained an equimolar concentration of sucrose in place of $\mathrm{NaCl}$ (Aghajanian and Rasmussen, 1989). Rabbits were deeply anesthetized with halothane and decapitated, and the brain was exposed and quickly hemisected in situ, removed (within $50 \mathrm{sec}$ ), and incubated in ice-cold $\left(<1^{\circ} \mathrm{C}\right)$ oxygenated sucroseaCSF for $\sim 4$ min. Both hippocampi were quickly dissected out, cut into two $4 \mathrm{~mm}$ chunks, and glued to a small, chilled chamber that was then filled with ice-cold oxygenated sucrose-aCSF. Slices $(400 \mu \mathrm{m})$ were cut using a vibratome and placed in an aCSF-filled holding chamber at room temperature $\left(\sim 23^{\circ} \mathrm{C}\right)$ for at least $45 \mathrm{~min}$. For recording, slices were individually transferred to a submersion chamber (Medical Systems, Greenvale, NY) and continuously perfused $(\sim 1.75 \mathrm{ml} / \mathrm{min})$ with oxygenated aCSF at $31^{\circ} \mathrm{C}$. Using this procedure, we routinely recorded from three to five healthy hippocampal pyramidal neurons per rabbit, with slices remaining viable for up to $10 \mathrm{hr}$ without displaying epileptiform burst activity.

Electrophysiological recording and data analysis. Intracellular recordings were made from $215 \mathrm{CA} 1$ pyramidal neurons using an Axoclamp 2A amplifier (Axon Instruments, Foster City, CA) and thin-walled microelectrodes filled with $3 \mathrm{M} \mathrm{KCl} \mathrm{(20-50} \mathrm{M} \Omega$ ). Bipolar tungsten stimulating electrodes were placed in the alveus (or fimbria/fornix) and Schaffer collaterals for antidromic and orthodromic stimulation, respectively (see Fig. 1D). Antidromic activation was successful in $>90 \%$ of all CA1 neurons tested. A CA1 neuron was classified as a pyramidal cell and was included in the study if it exhibited little spontaneous activity at rest, had an action potential amplitude $>70 \mathrm{mV}$ from threshold, had an action potential duration $>1.2 \mathrm{msec}$ from rise threshold to recrossing of the resting potential, had an input resistance $\geq 20 \mathrm{M} \Omega$, and had a stable resting membrane potential more negative than $-60 \mathrm{mV}$. Cells were studied at membrane potentials near $-65 \mathrm{mV}(\leq 0.2 \mathrm{nA}$ constant current injection, if necessary) to minimize variability caused by the influence of voltage-dependent changes on membrane conductances.

All neurons that were stable for at least 5 min after impalement were studied under current clamp using the following protocol. (1) Currentvoltage $(I-V)$ relations were studied using $400 \mathrm{msec}$ current injections (range -1.0 to $+0.2 \mathrm{nA}$ ). Input resistance was determined by measuring the plateau voltage deflection (last $75 \mathrm{msec}$ of the $400 \mathrm{msec}$ pulse) using a $-0.2 \mathrm{nA}$ hyperpolarizing current injection. The depolarizing sag was calculated as the difference between the peak amplitude (during the first $150 \mathrm{msec}$ ) and the plateau voltage deflection during a $-1.0 \mathrm{nA}$ hyperpolarizing current injection. (2) The postburst AHP was studied using a 100 msec depolarizing current injection sufficient to elicit reliably a burst of four action potentials. Starting from stimulus offset, the duration of the AHP was measured as the time required for the AHP to return to baseline for at least $10 \mathrm{msec}$ (maximum duration $5 \mathrm{sec}$ ). The peak AHP amplitude was calculated as the maximum negative voltage deflection 
(relative to prepulse baseline potential) during the first $250 \mathrm{msec}$ after current offset. The integrated area of the AHP was calculated from current offset for the entire duration of the AHP. A total of five AHP measurements were made from each cell. (3) Spike-frequency adaptation (accommodation) was studied using an $800 \mathrm{msec}$ depolarizing current injection of the same stimulus intensity used to study the AHP. Three samples were taken per cell, at $20 \mathrm{sec}$ intervals, and the number of action potentials elicited was noted. (4) Single action potential waveform characteristics were studied by stimulation of the Schaffer collaterals (orthodromic) and alveus or fimbria/fornix (antidromic). Five samples of each were taken per cell at $5 \mathrm{sec}$ intervals. For antidromic action potentials, the amplitude was measured relative to baseline and the width was measured at one-sixth peak amplitude. (5) Resting membrane potential was calculated as the difference in potential before and after withdrawing the microelectrode from the cell. Data from no more than two cells were recorded in a given slice. The slice was changed if a cell was lost during an experiment, if more than six penetrating tracks were attempted, or after completion of the second experiment. A parallel series of experiments was carried out on CA3 neurons (Thompson et al., 1996b). Periodically, data were recorded first from a CA1 and then from a CA3 neuron in a given slice.

All data were stored on video cassette using a digital data recorder (Instrutech). Data were played back from tape and analyzed using a Lab-NB board (National Instruments, Austin, TX) interfaced to a Macintosh IIci (Apple Computer, Cupertino, CA) using custom software. Analog-to-digital sampling rates were: $5 \mathrm{kHz}$ ( $I-V$ relations and AHPs), $10 \mathrm{kHz}$ (accommodations and APs), and $1 \mathrm{kHz}$ (membrane potentials). Analyses of digitized data were performed blind off-line using IGOR PRO (WaveMetrics, Lake Oswego, OR) on a Macintosh IIci. Statistical evaluations were performed using ANOVAs (StatView, Abacus Concepts, Berkeley, CA) to determine training effects with a repeatedmeasures design appropriate for the multiple measurements from each neuron. Significant main effects were evaluated using Scheffe post hoc tests. To gain additional insight regarding the distribution of changes within a given population, conditioning-specific changes in excitability of individual neurons were also defined relative to the naive population. Thus, the electrophysiological characteristics of a given cell were considered "changed" by conditioning if its data value fell beyond 2 SDs from the mean for the population of naive neurons studied. For a normally distributed population, $>95 \%$ of the sample lies within \pm 2 SD (Runyon et al., 1996), as was the case for our data from naive rabbits (see Fig. 2). All data are reported as the mean \pm SEM.

\section{RESULTS}

\section{Behavioral acquisition of trace eyeblink conditioning}

Rabbits required a mean of $565 \pm 49$ trials to reach the behavioral criterion of $80 \%$ CRs within an 80 trial trace-conditioning session (Fig. 1). Two populations of rabbits were used as behavioral controls: pseudoconditioned and slow-learning rabbits. To minimize cohort effects, pseudoconditioned rabbits were sessionmatched and received a similar number of training sessions as trace-conditioned rabbits $\left(F_{(7,49)}=0.822, p>0.57\right)$. A comparison between the first and last training sessions revealed that pseudoconditioned rabbits showed no statistically significant increase in CRs across training sessions, whereas trace-conditioned rabbits improved significantly [ $p<0.001$ (paired $t$ test); Fig. $1 A]$. There was no statistically significant difference in the number of CRs between trace and pseudoconditioned rabbits during the first session $\left(F_{(1,50)}=2.525\right.$, NS), arguing against the existence of a sampling bias between the populations studied. Slow-learning rabbits were a small subset of six rabbits that showed $<30 \% \mathrm{CRs}$ after at least 15 training sessions. Three rabbits from this population were randomly selected and shifted to the easier delay conditioning task (Disterhoft et al., 1994b; Thompson et al., 1996a) and rapidly acquired the task within 320 trials (data not shown), indicating no apparent sensory deficits. In addition, there were no significant differences in learning rates among any of the seven groups of trace-conditioned rabbits (Fig. $1 B ; F_{(6,39)}=0.987$, $p>0.45)$.

\section{Acquisition of trace eyeblink conditioning increased excitability of CA1 neurons}

Postburst AHPs were significantly reduced in CA1 neurons studied $24 \mathrm{hr}$ after acquisition of hippocampus-dependent trace eyeblink conditioning (Fig. $2 A$ ). This observation is similar to previous reports of learning-specific AHP reductions in CA1 (Disterhoft et al., 1986; Coulter et al., 1989; deJonge et al., 1990). The AHP results from an outward $\mathrm{K}^{+}$current, activated by calcium influx during a burst of action potentials, that serves to modulate postsynaptic excitability of many cell types including hippocampal and cortical pyramidal neurons (Hotson and Prince, 1980; Gustafsson and Wigström, 1981; Lancaster and Adams, 1986; Storm, 1990; Schwindt et al., 1992). A repeated-measures ANOVA for all cells indicated a significant difference in the amplitude of the AHP as a function of time after learning $\left(F_{(9,205)}\right.$ $=14.852, p<0.001)$. Examination of data from individual neurons revealed that reduced AHPs were observed in 12 of 28 CA1 neurons studied $24 \mathrm{hr}$ after learning. This was unlikely to be an artifact of cell selection, because the data from the naive population followed a normal distribution (see Fig. $2 A$, insets). Learningrelated effects on the postburst AHP were not confined to reductions in the peak amplitude alone. Both the duration $\left(F_{(9,205)}=\right.$ $7.012, p<0.001)$ and the integrated area $\left(F_{(9,205)}=12.323, p<\right.$ $0.001)$ of the AHP were also significantly reduced in cells from conditioned rabbits (see Table 1). In parallel studies, reductions were also observed in CA3 pyramidal neurons after the same hippocampus-dependent trace-conditioning task, although their much larger-amplitude, longer-duration AHPs (approximately $-13 \mathrm{mV}$ with a mean duration of $\sim 9100 \mathrm{msec}$ in CA3 from the same population of naive rabbits) left them with larger AHPs after learning (Thompson et al., 1996b). After learning, the AHPs from CA1 neurons tended to be smaller in size and shorter in duration than control neurons.

The reduced AHPs seen after learning were not attributable to differences in injected current, because the current required to fire a burst of four action potentials was not significantly different between the groups (mean current $\sim 0.65 \mathrm{nA} ; F_{(9,205)}=0.844$, $p=0.58$ ). Analyses of within-burst firing also revealed no statistically significant differences in within-burst interspike intervals between cells from control or trace-conditioned rabbits. The latencies (from current onset) to the peak of the first and fourth action potentials were calculated. A repeated-measures ANOVA revealed no statistically significant differences in the following: (1) latency to the first action potential (mean $6.3 \mathrm{msec} ; F_{(9,205)}=$ $0.296, p=0.98)$; (2) latency to the fourth action potential (mean $\left.\sim 72.0 \mathrm{msec} ; F_{(9,205)}=0.457, p=0.90\right)$; or (3) difference between the first and fourth action potential latencies (mean $\sim 67$ msec, $\left.F_{(9,205)}=0.441, p=0.91\right)$.

Spike-frequency adaptation (accommodation), another index of excitability, was also significantly reduced $24 \mathrm{hr}$ after acquisition of trace eyeblink conditioning $\left(F_{(9,205)}=10.064, p<0.001\right.$; Fig. $2 B$ ). This effect was not reported previously after conditioning in a delay eyeblink paradigm (Disterhoft et al., 1986), which is not hippocampus-dependent (Schmaltz and Theios, 1972; Akase et al., 1989). Hippocampal CA1 pyramidal neurons from control rabbits showed robust accommodation, which limited their withinburst firing frequencies during an $800 \mathrm{msec}$ current injection. Reduced accommodation was also observed in many individual CA1 pyramidal neurons studied $24 \mathrm{hr}$ after learning (13/28 cells).

There were no statistically significant differences in resting membrane potential, apparent input resistance, action potential 

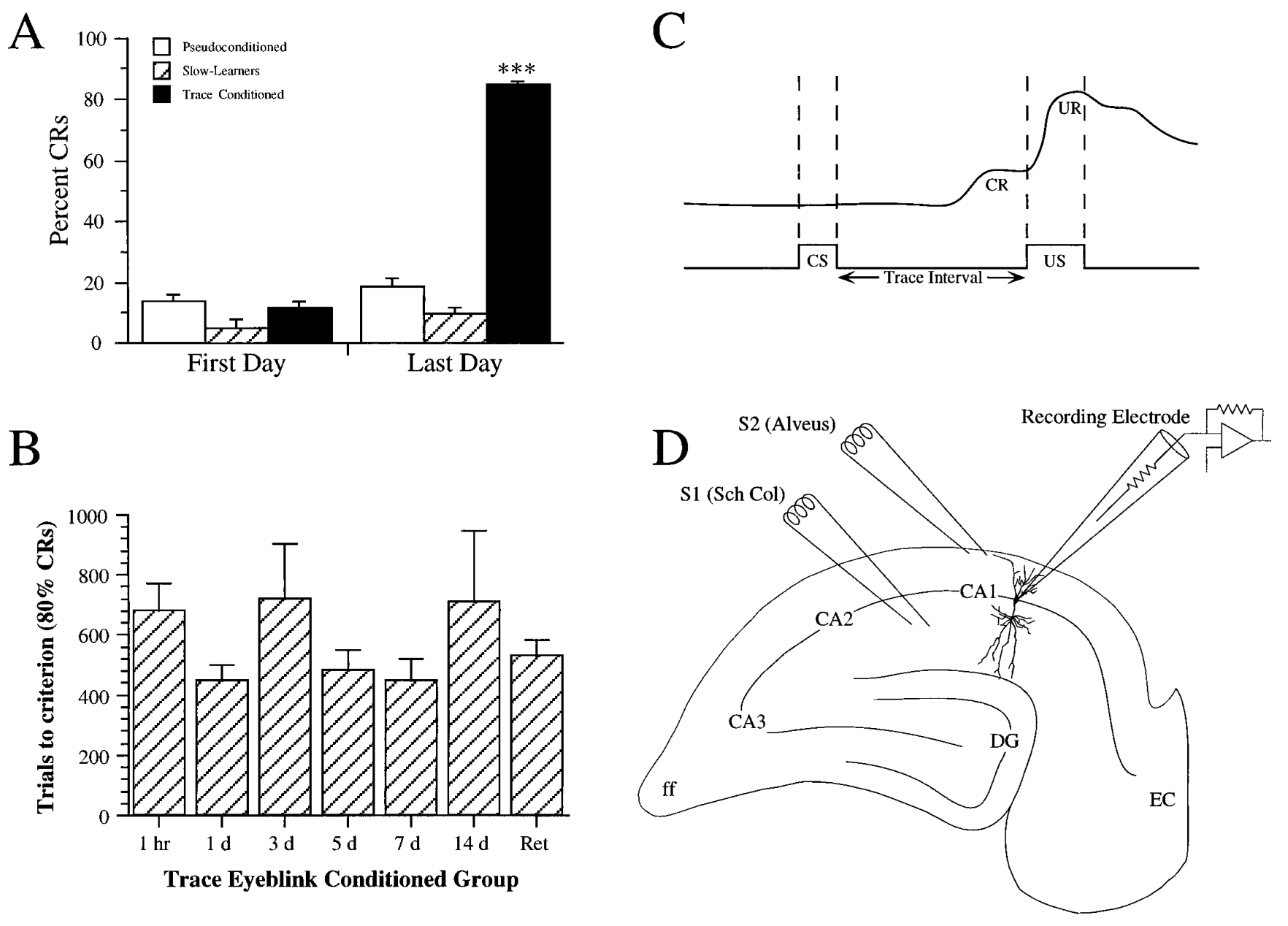

Figure 1. Acquisition of hippocampus-dependent trace eyeblink conditioning. A, Comparison between the first and last training sessions illustrated that rabbits in the trace-conditioned group showed significantly more CRs on the last day of training $(* * * p<0.001$, paired $t$ test), whereas rabbits in the pseudoconditioned or slow-learning control groups showed little or no improvement. $B$, Electrophysiological differences between groups did not result from differences in acquisition rates among the rabbits in the different trace-conditioning groups. A plot of trials to criterion for the various groups illustrates no significant differences between groups. $C$, Diagram illustrates the trace-conditioning paradigm used in the current study and shows a typical behavioral response after learning. As illustrated, presentation of the conditioned stimulus $(C S$; tone, $100 \mathrm{msec})$ results in a conditioned response (CR) that occurs during the trace (stimulus-free, $500 \mathrm{msec}$ ) interval but before onset of the unconditioned stimulus (US; corneal airpuff, $150 \mathrm{msec}$ ). Note that the CR precedes and overlaps with the unconditioned response (UR; eyeblink). $D$, Schematic diagram of a hippocampal slice indicating the typical location of the stimulation electrodes $(S 1$ and $S 2)$ used for orthodromic and antidromic activation of CA1 pyramidal cells. The recording electrode was placed in the pyramidal cell layer of CA1. ff, Fimbria/fornix; $D G$, dentate gyrus; $E C$, entorhinal cortex; Sch Col, Schaffer collaterals.

amplitude, or action potential duration observed in cells from the trace-conditioned or control rabbits (Table 2), indicating that the reduced AHPs seen after learning did not result from other voltage-dependent differences. However, when CA1 neurons were injected with a large $(-1.0 \mathrm{nA}, 400 \mathrm{msec})$ hyperpolarizing current, there was a small but statistically significant increase in the depolarizing "sag" potential at some intervals after trace conditioning (see Table 1). The current that contributes to this depolarizing sag is thought to be a $\mathrm{Cs}^{+}$-sensitive, TTX/TEA-insensitive inward current carried by $\mathrm{Na}^{+}$and $\mathrm{K}^{+}$ions, termed $I_{\mathrm{Q}}$ or $I_{\mathrm{h}}$ (Halliwell and Adams, 1982; Colino and Halliwell, 1993). Previous in vitro studies have reported inconsistent changes in this depolarizing potential after delay conditioning (Disterhoft et al., 1986; Sanchez-Andres and Alkon, 1991). The relevance of a learningrelated change in sag to the excitability or the function of hippocampal CA1 neurons is unclear because it was activated at hyperpolarizing potentials, beyond the reversal potential of $\mathrm{K}^{+}$. However, it is interesting that in CA1 neurons, $I_{\mathrm{Q}}$ is increased by neurotransmitters such as acetylcholine and norepinephrine (Colino and Halliwell, 1993; Storm and Pedarzani, 1995), which also reduce both the postburst AHP and accommodation (Cole and Nicoll, 1983; Madison and Nicoll, 1986).

\section{Increased excitability of CA1 neurons was transient whereas behavioral retention was persistent}

Enhanced excitability observed in CA1 neurons after learning was transient. Postburst AHPs were significantly reduced in cells from slices prepared as early as $1 \mathrm{hr}$ after the session when rabbits reached behavioral criterion (earliest interval tested) and slowly decayed back to baseline over a 1 week time period (Fig. $3 A$ ). The effect was substantial, with $53 \%$ of cells studied $1 \mathrm{hr}$ after learning showing reduced AHP amplitudes. Similar findings were observed on the duration and integrated area of the AHP (Table 1). The AHPs remained significantly reduced in cells studied up to $5 \mathrm{~d}$ after learning, but by $7 \mathrm{~d}$ after learning $<5 \%$ of the CA1 cells studied had reduced AHPs with no statistically significant popu- 


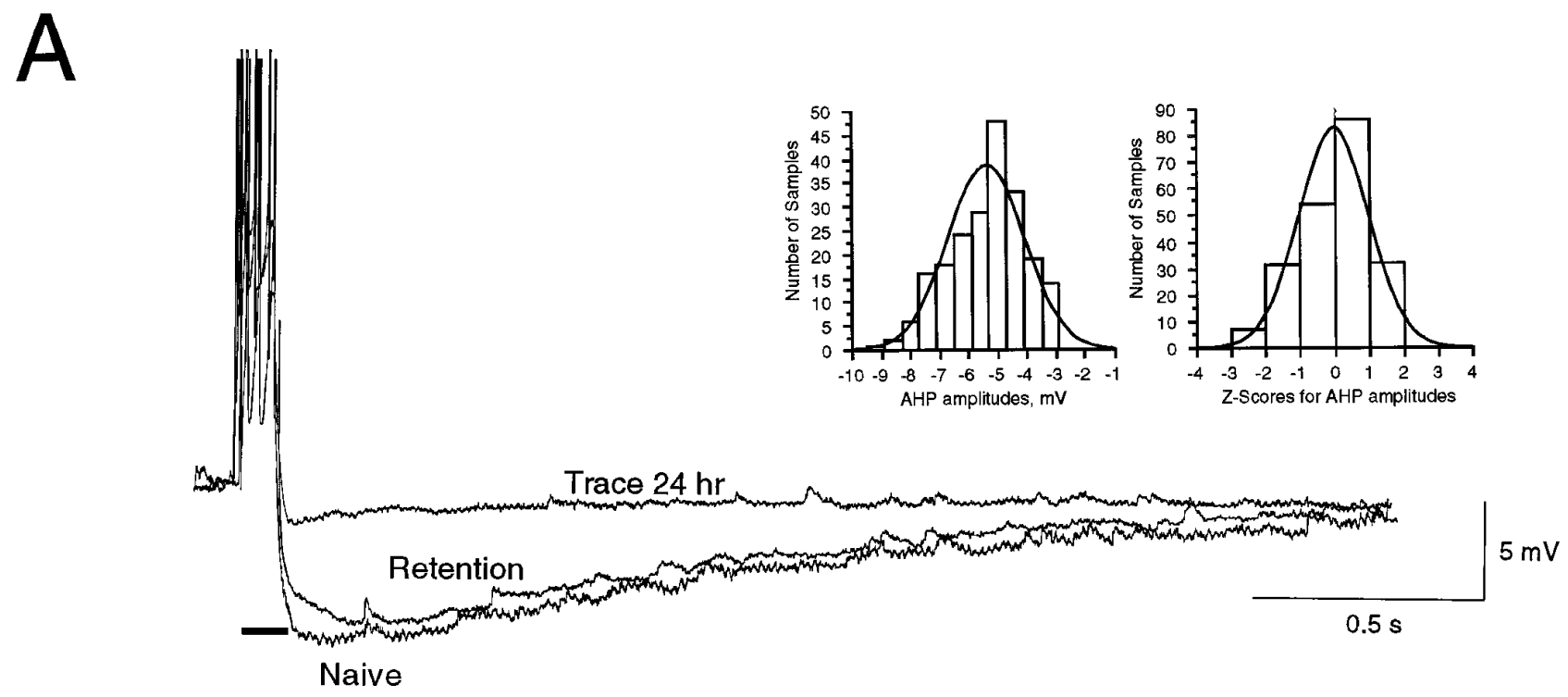

B

Pseudo

Trace $24 \mathrm{hr}$

Retention
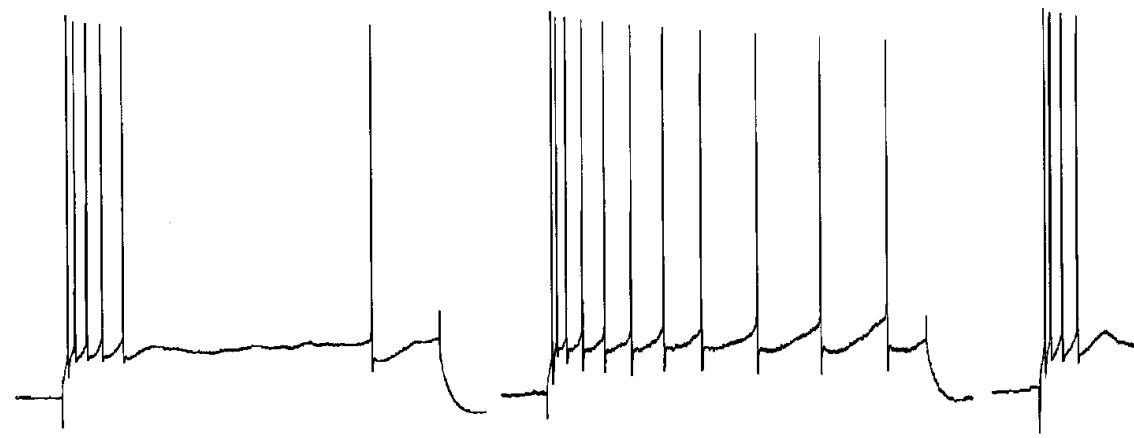

$20 \mathrm{mV}$

$0.2 \mathrm{~s}$

Figure 2. Acquisition of hippocampus-dependent trace eyeblink conditioning increased excitability of hippocampal CA1 pyramidal neurons. $A$, Voltage trace shows an overlay of recordings of the postburst AHPs in CA1 neurons from a naive rabbit (Naive) and from trace-conditioned rabbits studied 24 $\mathrm{hr}$ after initial learning (Trace $24 \mathrm{hr}$ ) or $24 \mathrm{hr}$ after receiving an additional training session given $14 \mathrm{~d}$ after initial learning (Retention). The resting membrane potentials for these cells were approximately $-66 \mathrm{mV}$, with action potentials truncated for visualization of the AHP. The AHP was measured for $5 \mathrm{sec}$ beginning after a $100 \mathrm{msec}$ depolarizing current injection (solid black line), with minimal current ( $\sim 0.6 \mathrm{nA}$ ) required to reliably evoke a burst of four action potentials. The postburst AHPs from experimentally naive rabbits followed a normal distribution as shown in the frequency distribution and $z$-score graphs (insets). B, Examples of typical accommodation responses in CA1 pyramidal cells from rabbits: $24 \mathrm{hr}$ after pseudoconditioning (Pseudo), $24 \mathrm{hr}$ after acquisition of trace conditioning (Trace $24 \mathrm{hr}$ ), and $24 \mathrm{hr}$ after receiving an additional training session $14 \mathrm{~d}$ after acquisition (Retention). Notice that although the cell from the trace-conditioned rabbit fired more action potentials, accommodation was certainly not abolished (as evidenced by the increase in interspike interval with time during the $800 \mathrm{msec}$ depolarizing stimulus) but, rather, was significantly and transiently reduced after learning.

lation effect. By $14 \mathrm{~d}$, postburst AHPs were indistinguishable from controls, and reduced AHPs were not seen in any of the 16 cells studied from 7 rabbits. The results were the same when data from individual cells, for each rabbit studied, were pooled to obtain a mean AHP amplitude value $\left(F_{(9,64)}=13.566, p<0.001\right)$. A similar trend (smaller AHPs) was also observed after data from cells with reduced AHPs (i.e., cells with AHPs 2 SDs smaller than the mean of the naive population) were removed from each of the groups $\left(F_{(9,168)}=5.994, p<0.001\right)$. In this case, however, statistically significant differences were only observed when slices were prepared $1 \mathrm{~d}(p<0.05)$ and $3 \mathrm{~d}(p<0.01)$ after learning. This may reflect a shift to a more distributed effect of lesser magnitude in a larger population of cells as a function of time after acquisition. Note that the largest net reduction in the AHP was seen in slices prepared $3 \mathrm{~d}$ after learning, even though the percentage of cells with reduced AHPs was actually lower in this group than in the $1 \mathrm{~d}$ group (see Fig. $3 A$ ).

Spike-frequency adaptation was also transiently reduced after associative learning (Table 1, Fig. 3). Reduced accommodation was apparent as early as $1 \mathrm{hr}$ after learning, with $40 \%$ of the 15 CA1 neurons studied $1 \mathrm{hr}$ after learning firing more spikes per burst. Learning-related changes in accommodation began to decline by the third day after learning, whereas AHP reductions showed little evidence of decay until the seventh day after acquisition (Fig. 3A,B), suggesting either that other conductances (e.g., $I_{\mathrm{M}}$ or $I_{\mathrm{D}}$ ) that influence accommodation (Storm, 1990) were altered or that a nonlinear relationship between the AHP and accommodation exists. Our experiments were not designed to address this issue, but numerous in vitro studies that pharmacologically manipulated the slow AHP also demonstrated changes in 
Table 1. Summary of learning-related changes in rabbit CA1 neurons

\begin{tabular}{|c|c|c|c|}
\hline \multirow{2}{*}{$\begin{array}{l}\text { Group (number } \\
\text { of rabbits) }\end{array}$} & \multicolumn{2}{|c|}{ Postburst afterhyperpolarization $(n)$} & \multirow{2}{*}{$\frac{\text { Depolarizing sag }(n)}{\text { Mean }(\mathrm{mV})}$} \\
\hline & Duration (msec) & Area $(\mathrm{mV} \cdot \mathrm{msec})$ & \\
\hline Naive (16) & $3129.3 \pm 89.4(42)$ & $-5811 \pm 208(42)$ & $5.9 \pm 0.4(39)$ \\
\hline Slow learners (3) & $3257.4 \pm 140.3(11)$ & $-5503 \pm 301(11)$ & $5.7 \pm 0.5(11)$ \\
\hline Trace $1 \mathrm{~h}(6)$ & $2025.8 \pm 141.2(15)^{\S}$ & $-2665 \pm 290(15)^{\S}$ & $7.7 \pm 0.7(14)^{*}$ \\
\hline Trace 5 d (6) & $2213.0 \pm 122.9(21)^{\ddagger}$ & $-2703 \pm 205(21)^{\S}$ & $6.6 \pm 0.4(20)$ \\
\hline Trace 7 d (7) & $2900.4 \pm 115.7(22)$ & $-4799 \pm 231(22)$ & $6.8 \pm 0.6(22)$ \\
\hline Trace 14 d (7) & $3108.2 \pm 125.8(16)$ & $-5492 \pm 236(16)$ & $5.8 \pm 0.6(15)$ \\
\hline Retention (5) & $3138.3 \pm 113.7(18)$ & $-5385 \pm 244(33)$ & $5.6 \pm 0.7(18)$ \\
\hline
\end{tabular}

Significantly different from all control groups (Naive, Pseudoconditioned, Slow learners): ${ }^{*} p<0.05,{ }^{\ddagger} p<0.01,{ }^{\S} p<0.001$.

accommodation (Benardo and Prince, 1982; Haas and Konnerth, 1983; Haas and Greene, 1984; Madison and Nicoll, 1986; Malenka and Nicoll, 1986; Colino and Halliwell, 1987; Hedlund and Andersen, 1989; Moyer et al., 1992; Liu et al., 1993). Decreased accommodation suggests that hippocampal neurons would be more likely to fire action potentials to excitatory afferent inputs and may reflect the demand for hippocampal processing required for acquisition or consolidation of the trace eyeblink conditioning task (Solomon et al., 1986; Moyer et al., 1990; Kim et al., 1995). If so, the time required for return of these changes to control levels may represent all or part of the time period during which the hippocampus serves an important function for consolidation of the learned behavior.

The decay rate of learning-related changes in CA1 neurons studied at various time points after trace conditioning was not an artifact related to differences in behavioral acquisition. No statistically significant differences in learning rates were observed between the various populations of trace conditioned rabbits studied at different times after learning (Fig. $1 B$ ). Alternatively, the decay rate could reflect a decrease in behavioral performance over time, as might occur with forgetting. To test this hypothesis, rabbits were trace-conditioned to a behavioral criterion of $80 \% \mathrm{CRs}$, and $\mathrm{CR}$ retention (i.e., asymptotic performance of the $\mathrm{CR}$ ) was tested using 20 paired CS-US conditioning trials presented at various intervals ranging from 1 to $128 \mathrm{~d}$ after initial acquisition. Retention performance remained nearly asymptotic at all time intervals tested, evidence that the learned association was maintained or remembered (Fig. 3C). This suggests that the electrophysiological changes observed after learning were not directly related to retention of the $\mathrm{CR}$, because these changes returned to baseline within $7 \mathrm{~d}$, whereas rabbits maintained behavioral performance above criterion for months. Thus, increased excitability of CA1 neurons was not required for long-term retention of the learned association.

\section{Increased excitability after trace conditioning was learning- not memory-specific}

To evaluate further the time-dependent dissociation between behavioral retention and in vitro excitability changes, an additional group of rabbits was trained to criterion as described above and returned to their home cages for $14 \mathrm{~d}$ without additional training. On the 14th day, these rabbits received one 80 trial session of

Table 2. Properties of CA1 neurons that do not change after acquisition of trace eyeblink conditioning

\begin{tabular}{|c|c|c|c|c|}
\hline \multirow{2}{*}{$\begin{array}{l}\text { Group (number } \\
\text { of rabbits) }\end{array}$} & \multirow{2}{*}{$\frac{\text { Resting potential }(n)}{\text { Mean }(\mathrm{mV})}$} & \multirow{2}{*}{$\frac{\text { Input resistance }(n)}{\text { Mean }(\mathrm{M} \Omega)}$} & \multicolumn{2}{|c|}{ Action potential characteristics $(n)^{a}$} \\
\hline & & & Amplitude (mV) & Width (msec) \\
\hline Naive (16) & $-66.6 \pm 0.5(42)$ & $35.5 \pm 1.9(40)$ & $97.3 \pm 1.4(20)$ & $1.3 \pm .03(20)$ \\
\hline Pseudo (11) & $-66.8 \pm 0.8(24)$ & $35.3 \pm 1.8(24)$ & $94.7 \pm 1.6(13)$ & $1.3 \pm .04(13)$ \\
\hline Slow learners (3) & $-66.5 \pm 0.5(11)$ & $35.4 \pm 3.2(11)$ & $98.9 \pm 1.5(10)$ & $1.3 \pm .04(10)$ \\
\hline Trace $1 \mathrm{~h}(6)$ & $-67.7 \pm 0.9(15)$ & $39.1 \pm 2.8(14)$ & $96.9 \pm 3.4(11)$ & $1.4 \pm 0.1(11)$ \\
\hline Trace 24 h (9) & $-66.3 \pm 0.7(28)$ & $37.8 \pm 1.9(26)$ & $96.6 \pm 1.2(14)$ & $1.3 \pm .05(14)$ \\
\hline Trace 3 d (6) & $-67.0 \pm 0.7(18)$ & $38.2 \pm 1.9(17)$ & $96.5 \pm 2.3(12)$ & $1.3 \pm .06(12)$ \\
\hline Trace 5 d (6) & $-67.4 \pm 0.5(21)$ & $35.4 \pm 1.7(20)$ & $97.2 \pm 2.1(16)$ & $1.4 \pm .08(16)$ \\
\hline Trace 7 d (7) & $-66.8 \pm 0.8(22)$ & $36.3 \pm 2.0(22)$ & $93.8 \pm 1.9(14)$ & $1.4 \pm .03(14)$ \\
\hline Trace 14 d (7) & $-66.8 \pm 0.9(16)$ & $38.8 \pm 2.9(15)$ & $95.1 \pm 2.6(16)$ & $1.4 \pm .06(16)$ \\
\hline Retention (5) & $-65.9 \pm 0.8(18)$ & $35.7 \pm 2.1(18)$ & $94.5 \pm 2.0(18)$ & $1.4 \pm .03(18)$ \\
\hline
\end{tabular}

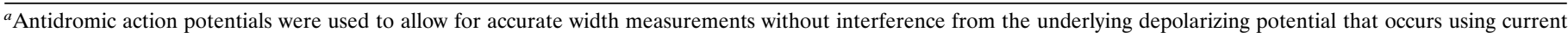
injection-evoked or orthodromically driven action potentials. 

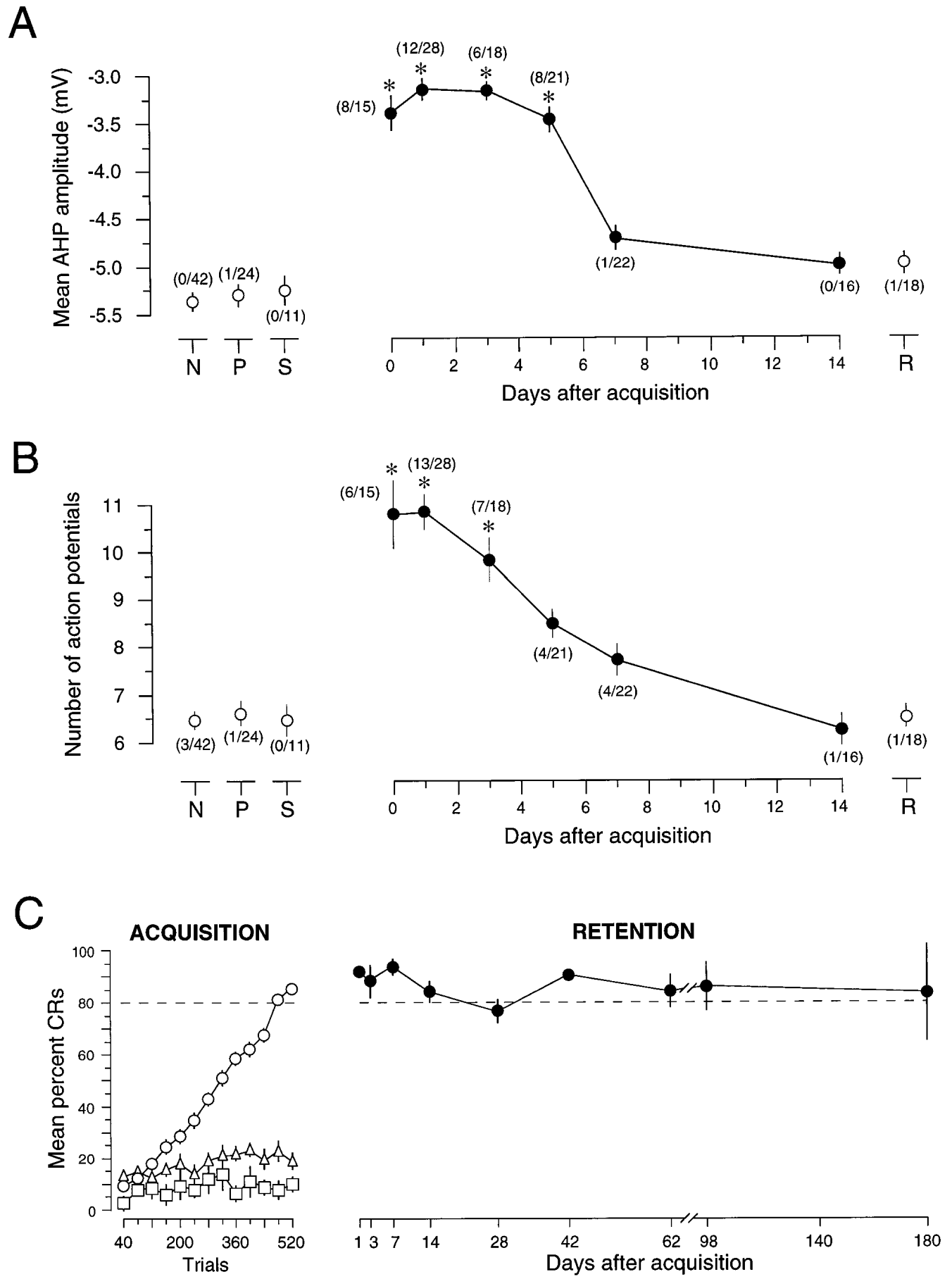

Figure 3. Increased excitability of CA1 pyramidal neurons after learning was transient while performance remained persistent. $A$, Learning-related reductions of the AHP amplitude were transient, lasting $\sim 1$ week in slices prepared at various times after learning $[1 \mathrm{hr}(0 \mathrm{~d}), 1 \mathrm{~d}, 3 \mathrm{~d}, 5 \mathrm{~d}, 7 \mathrm{~d}$, or $14 \mathrm{~d}]$. Such changes were not observed in naive $(N)$, pseudoconditioned $(P)$, or slow-learning $(S)$ control rabbits. Numbers in parentheses indicate the ratio of individual cells with reduced AHPs to number of cells studied in that group. Slow learners $(S)$ were defined as rabbits that did not reach criterion within 15 training sessions, and that exhibited $<30 \%$ conditioned responses on the last training session. Retention $(R)$ rabbits received an additional 80-trial training session on the 14th day after initial learning. $B$, Trace eyeblink conditioning also resulted in a transient decrease in spike-frequency adaptation (accommodation) in CA1 neurons. Cells from slow-learning or pseudoconditioned control rabbits showed no changes, nor did cells from retention rabbits that received an additional training session $14 \mathrm{~d}$ later. The ratio of individual cells with reduced accommodation versus the number of cells studied for each group is indicated in parentheses. A cell was classified as having reduced accommodation if the number of APs elicited was at least 2 SDs more than the mean for all naive control cells. $C$, After successful acquisition, rabbits maintained the learned association. The left panel (ACQUISITION) shows the normalized learning curves for trace conditioned compared with pseudoconditioned and slow-learning rabbits. Trace-conditioned rabbits $(\bigcirc, n=46)$ required an average of $7.1 \pm 0.6$ sessions to learn the task. As can be seen clearly, neither the pseudoconditioned $(\triangle, n=11)$ nor the slow-learning rabbits $(\square, n=3)$ showed significant improvement across sessions. Thus, the pseudoconditioned and slow-learning rabbits served as excellent controls for nonspecific effects of training unrelated to associative learning. The right panel (RETENTION) shows the percent CRs elicited during 20 paired CS-US trials delivered at various time intervals after acquisition. Notice that when retention rabbits $(\Theta, n=10)$ received 20 paired CS-US conditioning trials at the indicated times after learning, they maintained their criterion performance. For $A$ and $B$, asterisks indicate data significantly different from all three control groups: * $p<0.001$. 
trace eyeblink conditioning. Hippocampal slices were prepared 24 hr later. No excitability increases were observed in cells from this group (Figs. 2, 3), even though these rabbits retained the learned association near the behavioral criterion of $80 \%$ CRs. In fact, rabbits that received an 80 trial trace conditioning session $14 \mathrm{~d}$ after initial learning performed in a manner indistinguishable from that seen on the day they reached criterion $(87.7 \pm 2.6 \%$ CRs vs $82.3 \pm 6.4 \%$ CRs, $p>0.46$, paired $t$ test). This direct test, combined with the behavioral retention data above, suggests that increased excitability of CA1 [and CA3 (Thompson et al., 1996b)] pyramidal neurons is related to consolidation (and possibly acquisition), but not to post-learning performance or to long-term memory of the learned association.

\section{DISCUSSION}

Transient changes in postsynaptic excitability of CA1 pyramidal neurons were observed after acquisition of trace eyeblink conditioning. Significant reductions of both postburst AHP and accommodation were observed as early as $1 \mathrm{hr}$ after learning, were highly related to behavioral acquisition, and returned to normal within $14 \mathrm{~d}$. These data are the first to evaluate systematically how long postsynaptic changes in CA1 neurons last after acquisition of trace eyeblink conditioning, and they suggest that the hippocampus is not the final storage site for the learned association.

AHPs were reduced by $\sim 40 \%$ the day after learning, with $43 \%$ of individual CA1 pyramidal cells studied exhibiting reduced AHPs (Fig. 3). With smaller, shorter-duration AHPs, CA1 neurons can respond more readily to excitatory afferents. Such increased responsiveness could facilitate propagation of selective afferent information through the hippocampal circuit to other brain regions involved in the trace-conditioned reflex (Berger et al., 1976; Thompson, 1988; Kruppa et al., 1993; Disterhoft et al., 1994b; Weiss et al., 1996). A $68 \%$ increase in the number of action potentials elicited during an $800 \mathrm{msec}$ depolarizing current injection was also observed, with the effect present in $47 \%$ of the cells studied (Fig. $2 B$ ). These in vitro excitability changes were learningspecific. Such changes were not observed in CA1 neurons from either slow-learning rabbits (conditioned but did not learn, Fig. 3), as reported previously using delay eyeblink conditioning (Disterhoft et al., 1988b) or pseudoconditioned rabbits (Table 1), in agreement with previous in vitro and in vivo data (Berger et al., 1976, 1983; Disterhoft et al., 1986, 1988a; Solomon et al., 1986; deJonge et al., 1990). Increased excitability of CA1 neurons after learning was also independent of long-term memory and behavioral performance. When slices were prepared from rabbits that received an additional 80 trial training session 2 weeks after initially reaching criterion (Retention group), no postsynaptic changes were observed, even though the rabbits maintained $\geq 80 \%$ CRs (Fig. 3). These data illustrate a temporal dissociation between behavioral performance and altered postsynaptic excitability of CA1 neurons (Fig. 2, Table 1).

If postsynaptic reductions of the AHP are important correlates of learning, then it would follow that compounds that either reduce or increase the AHP should impact learning. We have directly tested one such compound, nimodipine, in aging rabbits. Nimodipine blocks L-type $\mathrm{Ca}^{2+}$ channels in CA1 neurons (Moyer et al., 1994a), readily crosses the blood-brain barrier (Van den Kerckhoff and Drewes, 1989), and increases basal firing rates of rabbit hippocampal pyramidal neurons in vivo (Thompson et al., 1990). It also reduces the plateau phase of calcium action potentials (Moyer and Disterhoft, 1994), reduces the calciumdependent slow AHP (Mazzanti et al., 1991; Moyer et al., 1992), and reduces accommodation in CA1 pyramidal cells in vitro (Moyer et al., 1992). Moreover, nimodipine significantly improves acquisition of trace eyeblink conditioning in aging rabbits (Deyo et al., 1989; Kowalska and Disterhoft, 1994), whose CA1 pyramidal neurons without nimodipine treatment have significantly enhanced AHPs (Moyer et al., 1992). Enhanced AHPs are also seen in aged rat CA1 neurons (Landfield and Pitler, 1984), illustrating the potentially significant relationship between postsynaptic excitability of CA1 neurons, aging-related learning deficits (Disterhoft et al., 1994a), and postsynaptic changes after associative learning (Disterhoft et al., 1989, 1994b). Also, post-training intraperitoneal injection of apamin (a bee venom that blocks the $\mathrm{Ca}^{2+}$-activated slow AHP) reduced the temporary drop in performance observed in retention sessions (i.e., a Kamin-like effect) in mice trained in an appetitive bar-pressing task (Belcadi-Abbassi and Destrade, 1995). Compounds that directly enhance the AHP have not been tested in eyeblink conditioning, but the nimodipine and apamin data suggest that such drugs would likely impair learning.

The time course of changes in excitability observed after learning is also notably convergent with recent behavioral data. Hippocampal lesions made $24 \mathrm{hr}$ after acquisition of trace eyeblink conditioning (when AHP reductions are maximal) eliminated CRs and prevented reacquisition, yet those made $30 \mathrm{~d}$ after acquisition (when AHP reductions have returned to baseline) had no effect on CR retention (Kim et al., 1995). These data support our observations that suggest that the hippocampus is not the longterm storage site for this behavioral task. Similar observations have been noted in other hippocampus-dependent learning tasks in other species (Zola-Morgan and Squire, 1990; Kim and Fanselow, 1992). The transient nature of increased excitability after learning also suggests that some regulatory process exists for restoring excitability to the normal baseline state, an important property for a mechanism supporting memory consolidation (Byrne, 1987).

Intracellular second messengers may constitute important switches for modulating neuronal excitability. For example, activation of kinases such as calcium/calmodulin-dependent protein kinase II (Müller et al., 1993), protein kinase A (Pedarzani and Storm, 1993), and protein kinase C (Malenka et al., 1986; Sakakibara et al., 1986) in vitro can create enhanced postsynaptic excitability in CA1 neurons, like those we observed after learning. Indeed, several studies demonstrated learning-related changes in kinases after acquisition of eyeblink conditioning tasks (Bank et al., 1988; Olds et al., 1989; Van der Zee et al., 1994). The contribution of second messengers to learning-related postsynaptic excitability changes remains to be evaluated.

Changes in postsynaptic excitability have important functional and theoretical implications. By incorporating specific features of $I_{\mathrm{AHP}}$ into the elements of a densely connected artificial neural network, it was demonstrated that increasing or decreasing the magnitude of $I_{\mathrm{AHP}}$ alone resulted in corresponding decreases or increases in network excitability (Berner, 1991). Observed in the absence of changes in synaptic weights, this suggests that $I_{\mathrm{AHP}}$ may play an important role in the timing of network outputs and the selection of different outputs from other networks. It was shown that physiological reductions of $I_{\mathrm{AHP}}$ increased the stability of stored patterns, whereas large increases reduced the correlation between network output and the stored pattern, i.e., memory and the recall of that memory (Berner, 1991). Such observations are intriguing because reduced AHPs have been observed in CA1 neurons in vitro after learning and because enhanced AHPs have been observed in CA1 neurons from aged animals (Landfield and Pitler, 1984; Moyer et al., 1992; Disterhoft et al., 1994a) that are 
significantly impaired in many learning tasks, including trace eyeblink conditioning (Thompson et al., 1996a). Another model based on empirical data demonstrated how general increases in postsynaptic excitability coupled with presynaptic, pathwayspecific modulation can prevent storage of incoming information from interfering with recall of previously formed associations (Hasselmo and Bower, 1993). This model suggests that cholinergic modulation within the hippocampus switches it between two different processing states: one in which afferent information is temporarily stored within the hippocampus and another in which this information is retrieved for transfer to another long-term storage site (Hasselmo, 1993; Hasselmo and Barkai, 1995). Postsynaptic alterations of both the postburst AHP and accommodation have been implicated in these models. These are particularly intriguing because the cholinergic antagonist scopolamine impairs acquisition of delay conditioning (Solomon, 1983; Harvey et al., 1985) and prevents acquisition of trace conditioning in rabbits (Kaneko and Thompson, 1995) and because acetylcholine application decreases the AHP and blocks accommodation in hippocampal neurons in vitro (Cole and Nicoll, 1983; Cole and Nicoll, 1984; Knöpfel et al., 1990). An interesting speculation is that scopolamine could compete and interfere with acetylcholine's modulation of postsynaptic excitability of CA1 neurons, thus impairing learning. Future interactions among behavioral, pharmacological, and computational studies might enable researchers to address such complicated interactions.

An important issue that warrants attention is how postsynaptic changes might govern learning and consolidation of the $\mathrm{CR}$ in trace conditioning without saturating the system, thus preventing acquisition of multiple or subsequent tasks. Although the effects observed here were substantial after learning, they were not complete. There still remained a substantial AHP that could be modulated further by other learning. It is entirely possible that the artificial salience of an associative learning paradigm in the daily life of laboratory rabbits, amplified the "signal-to-noise" ratio. Background information processing of the hippocampus may be lower in laboratory-bred rabbits as a result of being housed in a fairly stimulus-free environment, thus facilitating our ability to observe transient, learning-specific changes. We are not proposing that the postsynaptic changes observed after learning necessarily represent the mechanism by which information is stored within the hippocampus. The postsynaptic changes we observed may be a generalized effect of the learning process that facilitates storage of synapse-specific information by virtue of associativity between postsynaptic changes and patterned sets of convergent afferent and/or intrinsic inputs. Such associative plasticity may involve NMDA receptor (NMDAR) channel activity. For example, administration of D-cycloserine (a partial agonist at the glycine site on the NMDAR channel complex) facilitates acquisition of trace eyeblink conditioning in rabbits (Thompson et al., 1992), presumably through involvement of NMDA-mediated synaptic transmission (Power et al., 1995). We propose that the postsynaptic changes observed in the present study reflect the transient requirement of the hippocampus for both acquisition and postacquisition consolidation of the CR. Such temporal encoding likely occurs as a distributed pattern of network information either temporarily stored within the hippocampus and then secondarily transferred to a permanent site or stored directly in a more permanent storage site through continuous active interactions with the hippocampus (Alvarez and Squire, 1994).

Membrane conductance changes may represent one phylogenetically conserved correlate of learning. Such changes have been observed in both vertebrate (Disterhoft et al., 1986, 1988a; LoTurco et al., 1988; Coulter et al., 1989; deJonge et al., 1990; Woody et al., 1991; Moyer et al., 1993, 1994b; Power et al., 1995; Thompson et al., 1996b) and invertebrate (Klein and Kandel, 1978, 1980; Hawkins et al., 1983; Alkon, 1984; Crow, 1985a,b; Carew and Sahley, 1986; Scholz and Byrne, 1987; Hawkins et al., 1993) preparations. The convergence between observed reductions in calcium-activated potassium conductances across such diverse organisms as Hermissenda (Alkon, 1984) and rabbits (Disterhoft et al., 1986) illustrates the significance of these changes as conserved mechanisms of learning-related plasticity at the cellular level across phylogeny.

In conclusion, postsynaptic excitability of CA1 neurons is transiently increased by acquisition of trace eyeblink conditioning. Such changes are not required for long-term retention of the behavioral CR, but may contribute to consolidation of the learned behavior in other brain regions. Thus, evidence for time-limited, learning-related changes can be found at the cellular level using in vitro hippocampal slice preparations. These data should provide valuable information for developing biologically based computational models of hippocampal function, not only in trace eyeblink conditioning but also in other hippocampus-dependent learning tasks.

\section{REFERENCES}

Aghajanian GK, Rasmussen K (1989) Intracellular studies in the facial nucleus illustrating a simple new method for obtaining viable motoneurons in adult rat brain slices. Synapse 3:331-338.

Akase E, Alkon DL, Disterhoft JF (1989) Hippocampal lesions impair memory of short-delay conditioned eyeblink in rabbits. Behav Neurosci 103:935-943.

Akase E, Thompson LT, Disterhoft JF (1994) A system for quantitative analysis of associative learning. II. Real-time software for MS-DOS microcomputers. J Neurosci Methods 54:119-130.

Alkon DL (1984) Calcium-mediated reduction of ionic currents: a biophysical memory trace. Science 226:1037-1045.

Alvarez P, Squire LR (1994) Memory consolidation and the medial temporal lobe: a simple network model. Proc Natl Acad Sci USA 91:7041-7045.

Alvarez P, Zola-Morgan S, Squire LR (1995) Damage limited to the hippocampal region produces long-lasting memory impairment in monkeys. J Neurosci 15:3796-3807.

Bank B, deWeer A, Kuzirian AM, Rasmussen H, Alkon DL (1988) Classical conditioning induces long-term translocation of protein kinase $\mathrm{C}$ in rabbit hippocampal CA1 cells. Proc Natl Acad Sci USA 85:1988-1992.

Belcadi-Abbassi W, Destrade C (1995) Post-test apamin injection suppresses a Kamin-like effect following a learning session in mice. NeuroReport 6:1293-1296.

Benardo LS, Prince DA (1982) Ionic mechanisms of cholinergic excitation in mammalian hippocampal pyramidal cells. Brain Res 249:333-344.

Berger TW, Alger B, Thompson RF (1976) Neuronal substrate of classical conditioning in the hippocampus. Science 192:483-485.

Berger TW, Rinaldi PC, Weisz DJ, Thompson RF (1983) Single-unit analysis of different hippocampal cell types during classical conditioning of rabbit nictitating membrane response. J Neurophysiol 50:1197-1219.

Berner J (1991) Functional roles for the slow afterhyperpolarization: inferences from incorporation of features of the slow $\mathrm{gK}^{+}(\mathrm{Ca})$ into densely connected artificial neural networks. Network 2:1-6.

Buzsáki G (1989) Two-stage model of memory trace formation: a role for "noisy" brain states. Neuroscience 31:551-570.

Byrne JH (1987) Cellular analysis of associative learning. Physiol Rev 67:329-439.

Carew TJ, Sahley CL (1986) Invertebrate learning and memory: from behavior to molecules. Annu Rev Neurosci 9:435-487.

Carew TJ, Walters ET, Kandel ER (1981) Classical conditioning in a simple withdrawal reflex in Aplysia californica. J Neurosci 1:1426-1437.

Cohen NJ, Eichenbaum H (1993) Memory, amnesia, and the hippocampal system. Cambridge: MIT. 
Cole AE, Nicoll RA (1983) Acetylcholine mediates a slow synaptic potential in hippocampal pyramidal cells. Science 221:1299-1301.

Cole AE, Nicoll RA (1984) Characterization of a slow cholinergic postsynaptic potential recorded in vitro from rat hippocampal pyramidal cells. J Physiol (Lond) 352:173-188.

Colino A, Halliwell JV (1987) Differential modulation of three separate K-conductances in hippocampal CA1 neurons by serotonin. Nature 328:73-77.

Colino A, Halliwell JV (1993) Carbachol potentiates Q current and activates a calcium-dependent non-specific conductance in rat hippocampus in vitro. Eur J Neurosci 5:1198-1209.

Coulter DA, LoTurco JJ, Kubota M, Disterhoft JF, Moore JW, Alkon DL (1989) Classical conditioning reduces the amplitude and duration of the calcium-dependent afterhyperpolarization in rabbit hippocampal pyramidal cells. J Neurophysiol 61:971-981.

Crow T (1985a) Conditioned modification of phototactic behavior in Hermissenda. I. Analysis of light intensity. J Neurosci 5:209-214.

Crow T (1985b) Conditioned modification of phototactic behavior in Hermissenda. II. Differential adaptation of B photoreceptors. J Neurosci 5:215-223.

deJonge MC, Black JP, Deyo RA, Disterhoft JF (1990) Learninginduced afterhyperpolarization reductions in hippocampus are specific for cell type and potassium conductance. Exp Brain Res 80:456-462.

Deyo RA, Straube KT, Disterhoft JF (1989) Nimodipine facilitates associative learning in aging rabbits. Science 243:809-811.

Disterhoft JF, Coulter DA, Alkon DL (1986) Conditioning-specific membrane changes of rabbit hippocampal neurons measured in vitro. Proc Natl Acad Sci USA 83:2733-2737.

Disterhoft JF, Coulter DA, Alkon DL (1988a) Conditioning-specific biophysical alterations in rabbit hippocampus. In: Cellular mechanisms of conditioning and behavioral plasticity (Woody CD, Alkon DL, McGaugh JL, eds), pp 89-104. New York: Plenum.

Disterhoft JF, Golden DT, Read HL, Coulter DA, Alkon DL (1988b) AHP reductions in rabbit hippocampal neurons during conditioning correlate with acquisition of the learned response. Brain Res 462:118-125.

Disterhoft JF, Deyo RA, Moyer Jr JR, Straube KT, Thompson LT (1989) Calcium blockers and memory in the aging brain. Cardiovasc Rev Rep 10:22-29.

Disterhoft JF, Moyer Jr JR, Thompson LT, Cutting FB, Power JM (1994a) In vitro analyses of aging-related learning deficits. Soc Neurosci Abstr 20:796.

Disterhoft JF, Thompson LT, Moyer Jr JR (1994b) Cellular mechanisms of associative learning in the hippocampus. In: The memory system of the brain (Delacour J, ed), pp 431-492. Singapore: World Scientific.

Frysztak RJ, Crow T (1994) Enhancement of type B and A photoreceptor inhibitory synaptic connections in conditioned Hermissenda. J Neurosci 14:1245-1250.

Gustafsson B, Wigström H (1981) Evidence for two types of afterhyperpolarization in CA1 pyramidal cells in the hippocampus. Brain Res 206:462-468.

Haas H, Greene R (1984) Adenosine enhances AHP and accommodation in hippocampal pyramidal cells. Pflügers Arch 402:244-247.

Haas HL, Konnerth A (1983) Histamine and noradrenaline decrease calcium-activated potassium conductance in hippocampal pyramidal cells. Nature 302:432-434.

Halliwell JV, Adams PR (1982) Voltage-clamp analysis of muscarinic excitation in hippocampal neurons. Brain Res 250:71-92.

Harvey JA, Gormezano I, Cool-Hauser VA (1985) Relationship between heterosynaptic reflex facilitation and acquisition of the nictitating membrane response in control and scopolamine-injected rabbits. J Neurosci 5:595-602.

Hasselmo ME (1993) Acetylcholine and learning in a cortical associative memory. Neural Comput 5:32-44.

Hasselmo ME, Barkai E (1995) Cholinergic modulation of activitydependent synaptic plasticity in the piriform cortex and associative memory function in a network biophysical simulation. J Neurosci 15:6592-6604.

Hasselmo ME, Bower JM (1993) Acetylcholine and memory. Trends Neurosci 16:218-222.

Hawkins RD, Abrams TW, Carew TJ, Kandel ER (1983) A cellular mechanism of classical conditioning in Aplysia: activity-dependent amplification of presynaptic facilitation. Science 219:400-404.
Hawkins RD, Kandel ER, Siegelbaum SA (1993) Learning to modulate transmitter release: themes and variations in synaptic plasticity. Annu Rev Neurosci 16:625-665.

Hebb DO (1949) The organization of behavior: a neurophysiological theory. New York: Wiley.

Hedlund B, Andersen P (1989) Alaproclate increases the excitability of hippocampal CA1 pyramidal cells and blocks the slow afterhyperpolarization. Pharmacol Toxicol 65:185-188.

Hotson JR, Prince DA (1980) A calcium-activated hyperpolarization follows repetitive firing in hippocampal neurons. J Neurophysiol 43:409-419.

Kaneko T, Thompson RF (1995) Suppression of rabbit's traceconditioning nictitating membrane response by scopolamine. Soc Neurosci Abstr 21:1222.

Kim JJ, Fanselow MS (1992) Modality-specific retrograde amnesia of fear. Science 256:675-677.

Kim JJ, Clark RE, Thompson RF (1995) Hippocampectomy impairs the memory of recently, but not remotely, acquired trace eyeblink conditioned responses. Behav Neurosci 109:195-203.

Klein M, Kandel ER (1978) Presynaptic modulation of voltagedependent $\mathrm{Ca}^{2+}$ current: mechanism for behavioral sensitization in Aplysia californica. Proc Natl Acad Sci USA 75:3512-3516.

Klein M, Kandel ER (1980) Mechanism of calcium current modulation underlying presynaptic facilitation and behavioral sensitization in Aplysia. Proc Natl Acad Sci USA 77:6912-6916.

Knöpfel T, Vranesic I, Gähwiller BH, Brown DA (1990) Muscarinic and $\alpha$-adrenergic depression of the slow $\mathrm{Ca}^{2+}$-activated potassium conductance in hippocampal CA3 pyramidal cells is not mediated by a reduction of depolarization-induced cytosolic $\mathrm{Ca}^{2+}$ transients. Proc Natl Acad Sci USA 87:4083-4087.

Kowalska M, Disterhoft JF (1994) Dose- and concentration-dependent effect of nimodipine on learning rate of aging rabbits. Exp Neurol 127:159-166.

Kruppa DJ, Thompson JK, Thompson RF (1993) Localization of a memory trace in the mammalian brain. Science 260:989-991.

Lancaster B, Adams PR (1986) Calcium-dependent current generating the afterhyperpolarization of hippocampal neurons. J Neurophysiol 55:1268-1282.

Landfield PW, Pitler TA (1984) Prolonged $\mathrm{Ca}^{2+}$-dependent afterhyperpolarizations in hippocampal neurons of aged rats. Science 226:1089-1092.

Liu YB, Disterhoft JF, Slater NT (1993) Activation of metabotropic glutamate receptors induces long-term depression of GABAergic inhibition in hippocampus. J Neurophysiol 69:1000-1004.

LoTurco JJ, Coulter DA, Alkon DL (1988) Enhancement of synaptic potentials in rabbit CA1 pyramidal neurons following classical conditioning. Proc Natl Acad Sci USA 85:1672-1676.

Madison DV, Nicoll RA (1986) Actions of noradrenaline recorded intracellularly in rat hippocampal CA1 pyramidal neurones, in vitro. J Physiol (Lond) 372:221-244.

Malenka RC, Nicoll RA (1986) Dopamine decreases the calciumactivated afterhyperpolarization in hippocampal CA1 pyramidal cells. Brain Res 379:210-215.

Malenka RC, Madison DV, Andrade R, Nicoll RA (1986) Phorbol esters mimic some cholinergic actions in hippocampal pyramidal neurons. J Neurosci 6:475-480.

Mazzanti ML, Thibault O, Landfield PW (1991) Dihydropyridine modulation of normal hippocampal physiology in young and aged rats. Neurosci Res Commun 9:117-126.

McGaugh JL (1966) Time-dependent processes in memory storage. Science 153:1351-1358.

McGaugh JL, Alperin HP (1966) Effects of electroshock on memory: amnesia without convulsions. Science 152:665-666.

McGaugh JL, Herz MJ (1972) Memory consolidation. San Francisco: Albion.

Moyer Jr JR, Disterhoft JF (1994) Nimodipine decreases calcium action potentials in an age- and concentration-dependent manner. Hippocampus 4:11-18.

Moyer Jr JR, Deyo RA, Disterhoft JF (1990) Hippocampectomy disrupts trace eye-blink conditioning in rabbits. Behav Neurosci 104:243-252.

Moyer Jr JR, Thompson LT, Black JP, Disterhoft JF (1992) Nimodipine increases excitability of rabbit CA1 pyramidal neurons in an age- and concentration-dependent manner. J Neurophysiol 68:2100-2109. 
Moyer Jr JR, Thompson LT, Disterhoft JF (1993) Hippocampallydependent trace eyeblink conditioning increases excitability of rabbit CA1 neurons in vitro. Soc Neurosci Abstr 19:801.

Moyer Jr JR, Disterhoft JF, Black JP, Yeh JZ (1994a) Dihydropyridinesensitive calcium channels in acutely-dissociated hippocampal CA1 neurons. Neurosci Res Commun 15:39-48.

Moyer Jr JR, Thompson LT, Disterhoft JF (1994b) The hippocampus as an intermediate storage buffer after associative learning: in vitro evidence from rabbit CA1. Soc Neurosci Abstr 20:796.

Müller GE, Pilzecker A (1900) Experimentelle beiträge zur lehre vom gedächtniss. Z Psychol 1:1-288.

Müller W, Petrozzino JJ, Griffith LC, Danho W, Connor JA (1993) Specific involvement of $\mathrm{Ca}^{2+}$-calmodulin kinase II in cholinergic modulation of neuronal responsiveness. J Neurophysiol 68:2264-2269.

Olds JL, Anderson ML, McPhie DL, Staten LD, Alkon DL (1989) Imaging of memory-specific changes in the distribution of protein kinase-C in the hippocampus. Science 245:866-869.

Pedarzani P, Storm JF (1993) PKA mediates the effects of monoamine transmitters on the $\mathrm{K}^{+}$current underlying slow spike frequency adaptation in hippocampal neurons. Neuron 11:1023-1035.

Power JM, Thompson LT, Moyer Jr JR, Disterhoft JF (1995) Increased synaptic responsiveness between $\mathrm{CA} 3$ and CA1 after trace eyeblink conditioning recorded in vitro. Soc Neurosci Abstr 21:1931.

Rawlins JNP (1985) Associations across time: the hippocampus as a temporary memory store. Behav Brain Sci 8:479-496.

Runyon RP, Haber A, Pittenger DJ, Coleman KA (1996) Fundamentals of behavioral statistics, 8th Ed. New York: McGraw-Hill.

Sakakibara M, Alkon DL, DeLorenzo R, Goldenring JR, Neary JT, Heldman E (1986) Modulation of calcium-mediated inactivation of ionic currents by $\mathrm{Ca}^{2+} /$ calmodulin-dependent protein kinase II. Biophys J 50:319-327.

Sanchez-Andres JV, Alkon DL (1991) Voltage-clamp analysis of the effects of classical conditioning on the hippocampus. J Neurophysiol 65:796-807.

Schmaltz LW, Theios J (1972) Acquisition and extinction of a classically conditioned response in hippocampectomized rabbits (Oryctolagus $\mathrm{cu}$ niculus). J Comp Physiol Psychol 79:328-333.

Scholz KP, Byrne JH (1987) Long-term sensitization in Aplysia: biophysical correlates in tail sensory neurons. Science 235:685-687.

Schwindt P, Spain WJ, Crill WE (1992) Calcium-dependent potassium currents in neurons from cat sensorimotor cortex. J Neurophysiol 67:216-226.

Scoville WB, Milner B (1957) Loss of recent memory after bilateral hippocampal lesions. J Neurol Neurosurg Psychiatry 20:11-21.

Solomon PR (1980) A time and a place for everything? Temporal processing views of hippocampal function with special reference to attention. Physiol Psychol 8:254-261.

Solomon PR, Solomon SD, vander Schaff EV, Perry HE (1983) Altered activity in the hippocampus is more detrimental to classical conditioning than removing the structure. Science 220:329-331.

Solomon PR, vander Schaff E, Thompson RF, Weisz DJ (1986) Hippocampus and trace conditioning of the rabbit's classically conditioned nictitating membrane response. Behav Neurosci 100:729-744.

Squire LR (1986) Mechanisms of memory. Science 232:1612-1619.
Squire LR (1987) Memory and brain. New York: Oxford UP.

Storm JF (1990) Potassium currents in hippocampal pyramidal cells. Prog Brain Res 83:161-187.

Storm JF, Pedarzani P (1995) Norepinephrine and cyclic AMP modulates the $\mathrm{Q} / \mathrm{H}$-current independently of protein kinase $\mathrm{A}$ in hippocampal neurons. Soc Neurosci Abstr 21:505.

Thompson LT, Deyo RA, Disterhoft JF (1990) Nimodipine enhances spontaneous activity of hippocampal pyramidal cells in aging rabbits at a dose that facilitates learning. Brain Res 535:119-130.

Thompson LT, Moskal JR, Disterhoft JF (1992) Hippocampusdependent learning facilitated by a monoclonal antibody or D-cycloserine. Nature 359:638-641.

Thompson LT, Moyer Jr JR, Akase E, Disterhoft JF (1994) A system for quantitative analysis of associative learning. I. Hardware interfaces with cross-species applications. J Neurosci Methods 54:109-117.

Thompson LT, Moyer Jr JR, Disterhoft JF (1996a) Trace eyeblink conditioning in rabbits demonstrates heterogeneity of learning ability both between and within age groups. Neurobiol Aging 17:619-629.

Thompson LT, Moyer Jr JR, Disterhoft JF (1996b) Transient changes in excitability of rabbit CA3 neurons with a time-course appropriate to support memory consolidation. J Neurophysiol, in press.

Thompson RF (1967) Foundations of physiological psychology, pp 599625. New York: Harper \& Row.

Thompson RF (1988) The neural basis of basic associative learning of discrete behavioral responses. Trends Neurosci 11:152-155.

Tocco G, Ramirez O, Nordholm A, Baudry M, Thompson RF (1993) Abolition of the rabbit nictitating membrane conditioned response by reversible inactivation of brain structures. Soc Neurosci Abstr 19:999.

Van den Kerckhoff W, Drewes LR (1989) Transfer of nimodipine and another calcium antagonist across the blood-brain barrier and their regional distribution in vivo. In: Diagnosis and treatment of senile dementia (Bergener M, Reisberg B, eds), pp 308-321. Berlin: Springer.

Van der Zee EA, Kronforst MA, Disterhoft JF (1994) Hippocampallydependent trace eyeblink conditioning changes the immunoreactivity for muscarinic acetylcholine receptors and $\mathrm{PKC} \gamma$ in the rabbit hippocampus. Soc Neurosci Abstr 20:1433.

Victor M, Agamanolis D (1990) Amnesia due to lesions confined to the hippocampus: a clinical-pathologic study. J Cognit Neurosci 2:246-257.

Walters ET, Byrne JH (1983) Associative conditioning of single sensory neurons suggests a cellular mechanism for learning. Science 219:405-408.

Weiss C, Kronforst-Collins MA, Disterhoft JF (1996) Activity of hippocampal pyramidal neurons during trace eyeblink conditioning. Hippocampus 6:192-209.

Woody CD, Gruen E, Birt D (1991) Changes in membrane currents during Pavlovian conditioning of single cortical neurons. Brain Res 539:76-84.

Zola-Morgan S, Squire LR (1990) The primate hippocampal formation: evidence for a time-limited role in memory storage. Science 250:288-290.

Zola-Morgan S, Squire LR, Amaral DG (1986) Human amnesia and the medial temporal region: enduring memory impairment following a bilateral lesion limited to field CA1 of the hippocampus. J Neurosci 6:2950-2967. 